\title{
PENINGKATAN KETERAMPILAN CREW DALAM PELAKSANAAN TANK CLEANING GUNA MENUNJANG KELANCARAN BONGKAR MUAT DI MT. BALONGAN
}

\author{
Agustyna C. ${ }^{a}$, Tri Kismantoro ${ }^{\text {b }}$ \\ ${ }^{a}$ Taruna Program Studi Nautika PIP Semarang \\ ${ }^{\mathrm{b}}$ Dosen Program Studi Nautika PIP Semarang
}

\begin{abstract}
ABSTRAK
Pembersihan tangki muatan (tank cleaning) merupakan salah satu kegiatan operasional kapal tanker yang sangat penting, dimana keberhasilan proses pemuatan berasal dari proses ini, dari sekian banyak jenis muatan kimia diantaranya adalah muatan yang sensitif sehingga dalam pemuatannya membutuhkan ruang muat yang benar-benar bersih dan terhindar dari zat-zat pencemar sehingga tangki dinilai layak untuk memuat muatan. Untuk menghasilkan ruang muat yang benar-benar bersih diperlukan pelaksanaan pembersihan tangki yang sesuai prosedur, dengan prasarana yang memadai, perencanaan dan koordinasi yang baik antara pihak-pihak terkait. Landasan teori yang digunakan dalam penulisan ini menjelaskan tentang prosedurprosedur pembersihan tangki di kapal tanker yang sesuai, karena keterlambatan akan menyebabkan kerugian yang besar bagi perusahaan. Penelitian dilakukan di atas kapal product tanker yang memuat avtur, penelitian dilakukan di atas kapal tentang proses pembersihan tangki muatan untuk meminimalkan kandungan zat-zat pencemar. Jenis penelitian yang terdapat dalam penulisan penelitian ini adalah kualitatif yaitu penelitian dengan mengumpulkan data-data di atas kapal MT. Balongan kemudian menganalisa dan mengambil kesimpulan yang berupa penjelasan. Berdasarkan hasil penelitian yang dilakukan di MT. Balongan, terdapat masalah yaitu pembersihan tangki yang dinyatakan gagal oleh surveyor. Kemudian menimbulkan keterlambatan dalam pemuatan dan perusahaan mengalami kerugian. Untuk mengantisipasi keterlambatan pemuatan, pembersihan tangki harus dilakukan sesuai panduan pembersihan tangki dengan perencanaan yang baik, ditunjang dengan sarana yang memadai, awak yang terampil dan jumlah yang cukup, serta koordinasi yang baik antara pihak-pihak terkait.
\end{abstract}

\section{Kata kunci : Keterampilan crew, tank cleaning, bongkar muat.}

\section{PENDAHULUAN}

\section{A. Latar Belakang}

Kapal Tanker merupakan salah satu sarana transportasi laut dari pelayaran niaga yang merupakan alat untuk mengangkut muatan cair atau mengangkut minyak hasil bumi. Sebuah kapal tanker dalam hal ini Product Oil Tanker adalah kapal tanker yang mengangkut berbagai jenis product oil atau minyak putih, seperti : premium, kerosine, avtur, high speed diesel (HSD), dan lain-lain. Kapal jenis ini juga yang menjadi tempat penulis menjalani proyek kerja laut selama satu tahun, yaitu kapal MT. Balongan.

Dalam mempersiapkan kapal, khususnya dalam persiapan tangki tentu pernah mengalami hambatan, berbagai masalah timbul menyangkut persiapan yang akan dilaksanakan, terutama saat mempersiapkan tangki untuk dimuati muatan khusus yang tidak boleh tercemar oleh benda atau muatan-muatan yang lain.

Berbagai muatan minyak jadi pernah dimuat di kapal tersebut di atas, salah satu muatan yang sering dimuat adalah avtur, dimana penanganan muatan ini termasuk yang paling mendapat perhatian khusus mengenai kesiapan serta pemuatan avtur itu sendiri.

Dalam perkembangan ilmu pengetahuan dan teknologi, kapal tanker juga mengalami pembaharuan sehingga dalam pelaksanaan tugas pengoperasian kapal semakin kompleks. Untuk itu perwira dan Anak Buah Kapal (ABK) 
diharuskan mampu menyesuaikan diri dan kemampuan diri dengan teknologi yang ada sehingga dapat melaksanakan kegiatan pemuatan dengan baik dan benar.

Untuk kelancaran pengoperasian kapal dibutuhkan adanya personil operasional lapangan dalam hal ini adalah crew deck yang mengerti dan menguasai tugasnya, terutama seorang Mualim yang dituntut bertanggungjawab untuk mengawasi proses memuat dan tank cleaning yang baik serta efisien. Dalam kegiatan bongkar muat pada kapal tanker yang memuat product oil seperti avtur, maka dalam hal ini tidak dapat dipisahkan dengan kegiatan pembersihan tangki yang baik dan benar serta efisien, pekerjaan yang sangat penting sebelum minyak dimuat ke dalam tangki. Maka tangki harus dalam keadaan bersih dan bebas dari gas sebelum menerima muatan minyak yang akan dimuat. Pada pelaksanaan tank cleaning ini, pembersihan tangki harus kering dan bebas gas. Semua kegiatan ini tidak lepas dari keahlian dan kecakapan para crew di atas kapal terutama crew deck yang dipimpin oleh Mualim I.

Maka dalam penulisan penelitian ini, penulis mengambil judul: "Peningkatan Keterampilan Crew Dalam Pelaksanaan Tank Cleaning Guna Menunjang Kelancaran Bongkar Muat MT. Balongan".

\section{B. Perumusan Masalah}

Beberapa masalah yang sering terjadi dalam proses tank cleaning maka penulis mengemukakan perumusan masalah pokok di dalam penelitian ini adalah:

1. Bagaimana cara meningkatkan keterampilan dan pemahaman Anak Buah Kapal (ABK) dalam pelaksanaan tank cleaning?

2. Hal-hal apa saja yang dapat dilakukan untuk mengatasi kurangnya interval waktu dalam pelaksanaan tank cleaning?

\section{Pembatasan Masalah}

Dalam penulisan ini, penulis hanya membahas mengenai upaya peningkatan keterampilan crew dalam pelaksanaan tank cleaning guna menunjang kelancaran bongkar muat di MT. Balongan.

\section{Tujuan Penelitian}

1. Untuk menunjang keterampilan anak buah kapal (ABK) yang bekerja di atas kapal tanker.

2. Untuk mencegah kerusakan muatan atau kontaminasi dari pada muatan yang diangkut.

\section{TINJAUAN PUSTAKA}

Menurut Peraturan Pemerintah Republik Indonesia Nomor 7 Tahun 2000 (Undang-Undang Republik Indonesia Nomor 17 Tahun 2008 tentang Pelayaran, 2010), pelaut adalah setiap orang yang mempunyai kualifikasi keahlian atau keterampilan sebagai awak kapal serta seseorang yang pekerjaannya berlayar di laut, atau dapat pula berarti seseorang yang mengemudikan kapal atau membantu dalam operasi, perawatan atau pelayanan dari sebuah Kapal. Hal ini mencakup seluruh orang yang bekerja di atas Kapal. Selain itu sering pula disebut dengan istilah Anak Buah Kapal atau ABK.

Di dalam aturan 3 (a) menyebutkan bahwa The world vessel includes every description of water craft, WIG craft and sea planes, used or capable of being used as a means of transportation on water dalam COLREG Convention on the International Regulations for Preventing Collisions at Sea, 1972 (2003: 6). Artinya bahwa kapal meliputi semua jenis pesawat air termasuk pesawat yang tidak memindahkan air dan pesawatpesawat terbang laut yang dipakai atau dapat dipakai sebagai alat pengangkut di atas air. Menurut G.S. Marton (Tanker Operation Fifth Edition 2007: 251), alasan pembersihan tangki adalah:

a. Pergantian muatan (change in cargo).

b. Perbaikan kerja atau pengecekan (repair work on inspection).

c. Pencegahan dari timbunan lumpur (prevention of sludge accumulatiuon). 
d. Persiapan dock (Preparation for shipyard)

e. Persiapan untuk pembebasan gas dan pengosongan tangki (Preparation for gasfreeing and tank entry)

Pelaksanaan pembersihan tangki (tank cleaning):

1. Precleaning (pencucian awal) Merupakan kegiatan penyemprotan tangki muat dengan butterworth setelah tangki kapal dinyatakan kering oleh surveyor. Alasan dilakukan precleaning adalah minyak dari muatan sebelumnya akan mudah dibersihkan, air yang digunakan dalam proses ini boleh menggunakan air laut atau air tawar, dingin atau panas, tetapi suhu minimal air adalah $20^{\circ} \mathrm{C}$.

2. Cleaning (pembersihan) Proses pembersihan ini adalah proses pembersihan tangki dengan tambahan (detergent, teepol, dan lain-lain). Dalam kasus tertentu jumlah detergen yang digunakan 1-3\% volume air laut yang digunakan, namun dalam kasus biasa $0,1 \%$ sudah cukup.

3. Rinsing (pencucian) Proses ini dilakukan setelah pembersihan air laut dan detergent, pembilasan dapat dilakukan dengan air laut yang dingin atau panas. Proses ini dapat dilakukan selama dua jam atau sampai tangki dinyatakan bersih dari bekas muatan yang sedang dibersihkan, dari residu atau sifat muatan yang sedang dibersihkan.

4. Flushing (pembilasan) Adalah pembilasan tangki dengan air tawar, kegiatan ini dilakukan sampai seluruh bagian tangki telah dibilas dengan air tawar.

5. Steaming (pemanasan) Kegiatan ini dilakukan untuk mengilangkan kadar hydrocarbon dan chloride dalam tangki. Pada saat proses ini tangki harus dalam keadaan tertutup tetapi tidak tertutup rapat, dan air dari hasil proses ini dipompa dengan cargo pump (pompa muatan) atau portable pump.

6. Draining (pengurasan) Kegiatan ini mengeringkan sisa-sisa air yang ada dalam tangki, cargo line (pipa muatan) dan pompa, semua plug dilepas dan dikeringkan dari air.

7. Drying and mooping (pengeringan dan pengepelan) Setelah pengeringan tangki dilakukan, sebelum memasuki tangki, harus dipastikan bahwa tangki telah mengalami pembebasan gas, kadar oxigen harus diantara $20-21 \%$ dan terbebas dari gas-gas beracun.

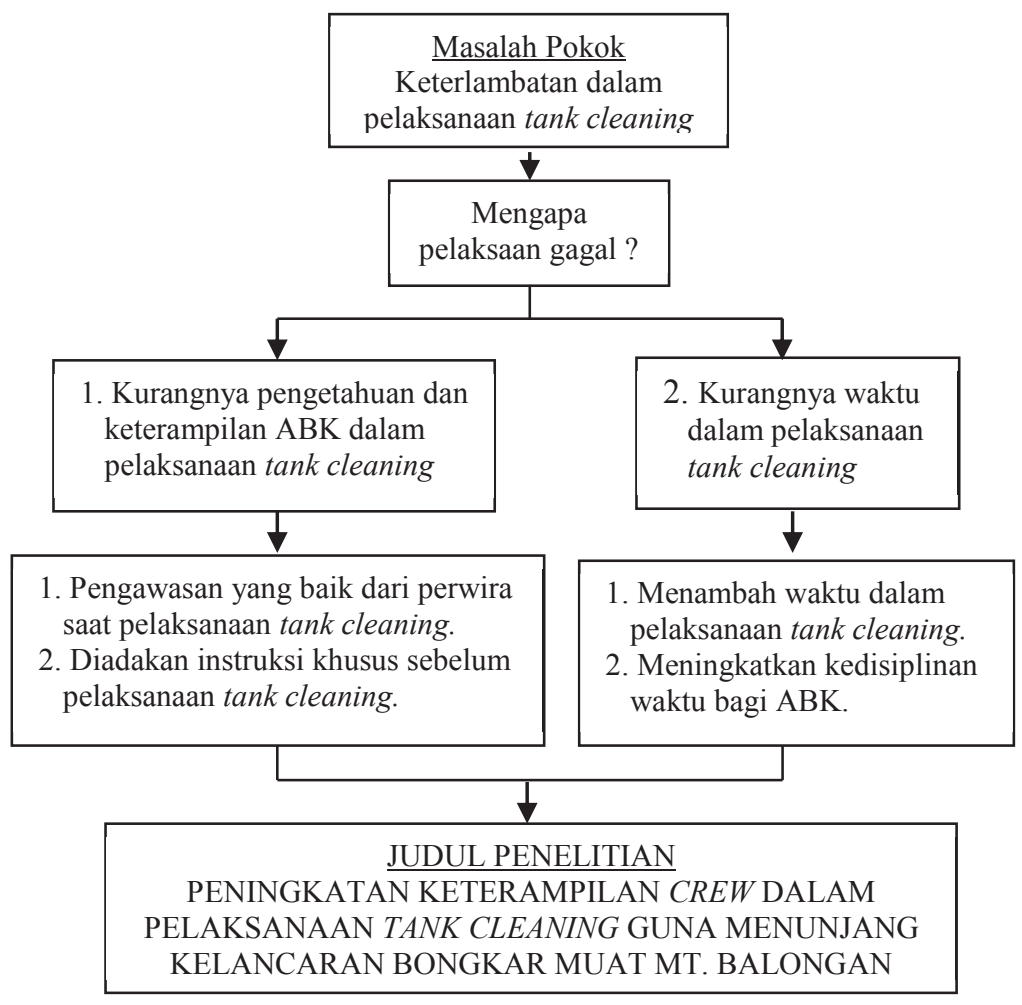

Gambar: Kerangka pikir pemecahan masalah 


\section{METODE PENELITIAN}

Menurut M. Toha Anggoro (2011: 1.1) Penelitian dapat diartikan sebagai proses mengumpulkan dan menganalisis data atau informasi secara sistematis sehingga menghasilkan kesimpulan yang sah. Metodologi penelitian adalah cara atau teknis yang dilakukan dalam penelitian. Sebuah penelitian harus berdasarkan pada material data yang akurat agar hasil dari penelitian tersebut dapat dipertanggungjawabkan baik secara ilmiah maupun secara kenyataan di lapangan sehingga hasil penelitian itu mempunyai nilai positif.

Jenis penelitian yang digunakan oleh penulis dalam penelitian ini adalah deskriptif kualitatif untuk menggambarkan dan menguraikan objek yang diteliti. Metode penelitian akan berisi kutipankutipan data untuk memberi gambaran penyajian data. Data tersebut berasal dari wawancara, catatan lapangan, foto, dokumen pribadi, catatan atau memo dan dokumen resmi lainnya. Penelitian ini merupakan penelitian non hipotesis sehingga dalam penelitiannya tidak perlu merumuskan hipotesis. Penelitian deskriptif yang bersifat eksploratif bertujuan untuk menggambarkan suatu fenomena. Metode lain yang dilakukan penulis adalah metode penelitian kualitatif yang sering disebut metode penelitian naturalistik karena penelitiannya dilakukan pada kondisi yang alamiah (natural setting).

Metode pengumpulan data dalam penyusunan penelitian ini penulis mengemukakan tentang metode pengumpulan data untuk memperoleh hasil yang baik, antara lain:

\section{Metode pengamatan}

Ada beberapa alasan mengapa dalam penelitian kualitatif pengamatan dimanfaatkan sebesar-besarnya seperti yang dikemukakan oleh Lexi J. Moleong (2006:174). Pertama, teknik pengamatan ini didasarkan atas pengalaman secara langsung. Kedua, teknik pengamatan juga memungkinkan melihat dan mengamati sendiri, kemudian mencatat perilaku dan kejadian sebagaimana yang terjadi pada keadaan yang sebenarnya. Ketiga, pengamatan memungkinkan peneliti mencatat peristiwa dalam situasi yang sebenarnya. Keempat, sering terjadi keraguan pada peneliti, jika pada data ada yang melenceng atau bias. Kelima, pengamatan yang memungkinkan penulis mampu memahami situasi-situasi rumit. Keenam, dalam kasus-kasus tertentu teknik komunikasi tidak dimungkinkan, maka pengamatan dapat menjadi alat yang sangat bermanfaat.

2. Metode kepustakaan

Studi kepustakaan adalah segala usaha yang dilakukan oleh peneliti untuk menghimpun informasi yang relevan dengan topik atau masalah yang akan atau sedang diteliti. Informasi itu dapat diperoleh dari buku-buku ilmiah, laporan penelitian, karangan-karangan ilmiah, tesis dan disertasi, peraturan-peraturan, ketetapan-ketetapan, daftar tahunan, ensiklopedia, dan sumber-sumber tertulis baik tercetak maupun elektronik lain.

3. Metode dokumentasi merupakan catatan peristiwa yang sudah berlalu

Dokumen bisa berbentuk tulisan atau karya-karya monumental dari seseorang. Studi dokumentasi merupakan pelengkap dari penggunaan metode observasi dan wawancara dalam penelitian kualitatif. Metode analisis data yang peneliti gunakan adalah metode analisis data deskriptif, karena penelitian ini bertujuan untuk untuk menjadikan hasil penelitian ini sebagai bahan rujukan dalam pelaksanaan tank cleaning yang telah diterapkan oleh MT. Balongan.

\section{HASIL PENELITIAN DAN PEMBAHASAN}

\section{Hasil Penelitian}

Kurangnya pengetahuan dan keterampilan khususnya $\mathrm{ABK}$ tentang pembersihan tangki yang baik dan benar.Proses awal sebelum kapal tanker melaksanakan operasional atau kegiatan memuat adalah persiapan ruang muat 
(tank cleaning). Persiapan ini sangat penting dan harus benar-benar diperhatikan, terutama muatan yang berlainan jenis, muatan yang sensitif atau muatan yang peka terhadap zat lain sehingga akan mudah rusak, contohnya avtur. Avtur adalah salah satu bahan bakar yang dipergunakan untuk bahan bakar pesawat. Oleh karena itu, kebersihan dan konsentrasinya harus benar-benar dijaga dengan baik agar tidak rusak. Terutama gas dari minyak lain seperti premium dan solar. Persenyawaan yang terjadi bisa menyebabkan ledakan pada saat avtur ini dipergunakan sehingga akan menimbulkan bahaya yang bisa merenggut nyawa pengguna. Kebersihan tangki dapat diketahui bila surveyor telah mengecek tiap-tiap tangki dan mengeluarkan dry certificate. Bila surveyor tidak mengeluarkan sertifikat tersebut maka tangki tersebut masih belum bersih dan belum siap untuk dimuati. Dalam pelaksanaan persiapan tangki diperlukan seorang perwira yang profesional dan mengetahui seluk beluk kapal dimana tempatnya bekerja dan didukung oleh ABK yang terampil sehingga mampu menyiapkan ruang muat dengan baik karena kapal dimana penulis melaksanakan praktek laut adalah kapal yang di-charter oleh perusahaan lain, maka kapal yang di-charter harus benarbenar memperhatikan waktu dan harus mempergunakan waktu seminim mungkin dengan baik.

Interval waktu yang kurang dalam proses tank cleaning. Dalam proses tank cleaning diperlukan waktu yang cukup agar proses tank cleaning yang dikerjakan mendapatkan hasil yang baik dan maksimal. Akan tetapi apa yang diharapkan itu tidaklah tercapai dengan baik dikarenakan route pelayaran yang cukup singkat yaitu sekitar 30 jam dari pelabuhan bongkar ke pelabuhan dimana kapal akan memuat. Dengan jumlah 10 buah tangki yang direncanakan akan dimuat avtur, maka proses pembersihan untuk 1 tangki saja membutuhkan waktu sekitar 5 jam agar tangki benar-benar bersih dan mendapatkan hasil yang baik. Jadi untuk membersihkan 10 tangki yang ada dibutuhkan waktu normal sekitar 50 jam, sedangkan waktu pelayaran hanya 30 jam. Maka waktu yang ada sangat kurang untuk melaksanakan proses pembersihan tangki. Ditambah lagi Mualim I dan satu orang juru mudi, baru bekerja selama 2 minggu di atas kapal. Pada awalnya Mualim I bekerja di kapal tanker jenis crude oil, yang jarang sekali melakukan tank cleaning, dan Juru mudi tersebut, sebelumnya bekerja di kapal container (peti kemas) dan belum pernah sekalipun bekerja di kapal tanker. Hal ini jelas menjadi beban tersendiri untuk melaksanakan tank cleaning yang baik dan tepat waktu.

Selama penulis menjalani praktek laut di atas kapal MT. Balongan, waktu yang diperlukan dalam pelaksanaan tank cleaning sangatlah kurang. Dimana untuk melakukan proses pembersihan tangki diperlukan waktu yang cukup agar hasilnya dapat maksimal, tetapi pada kenyataannya tidak. Oleh karena itu, keterbatasan waktu sangat menghambat pelaksanaan tank cleaning di atas kapal.

\section{Pembahasan Masalah}

Sesuai dengan apa yang telah diuraikan pada bab sebelumnya, maka penulis akan mengevaluasi terhadap pemecahan masalah antara lain:

a. Meningkatkan keterampilan dan pengetahuan anak buah kapal (ABK) tentang persiapan memuat. Salah satu kelemahan dari pelaut kita sekarang ini adalah pada masalah keterampilan dan pengetahuan yang masih minim, sehingga untuk menghasilkan pelaut yang terampil dan berkualitas sangat diperlukan peningkatan pengetahuan terhadap pekerjaan yang akan ditemui di atas kapal. Jika pelaut tersebut memiliki pengetahuan yang kurang, maka hal ini akan mengakibatkan terjadinya hambatan dalam proses pemuatan atau pembongkaran di atas kapal.

b. Meningkatkan pengawasan Mualim I dalam pelaksanaan tank cleaning. 
Agustyna C. ${ }^{a}$ dan Tri Kismantoro ${ }^{\text {b }}$

c. Perusahaan pelayaran harus bersedia untuk menyisihkan sebagian dana guna menyediakan suku cadang dan peralatan-peralatan yang dibutuhkan oleh pihak kapal.

d. Pihak perusahaan sebaiknya memberikan pelatihan terlebih dahulu kepada ABK yang baru bekerja di atas kapal, agar mereka mendapatkan gambaran pengetahuan tentang tata cara bekerja dan jenis-jenis dari muatan yang akan mereka temui di atas kapal pada saat kerja nanti.

e. Mualim I harus membuat suatu rencana kerja yang matang dan selalu memperhitungkan langkah-langkah yang akan digunakan jika nantinya terdapat kendala dalam pelaksanaan tank cleaning. Maka Mualim I bisa dengan cepat dan tanggap untuk mencari jalan keluar bagi masalah yang terjadi.

f. Sebagai seorang pemimpin di atas kapal, nakhoda harus memberikan contoh yang baik dalam bekerja dan melakukan tindakan dengan penuh rasa disiplin yang tinggi serta dapat dipertanggungjawabkan.

g. Mengutamakan keselamatan kerja dengan mengikuti peraturan-peraturan dan prosedur dalam pelaksanaannya.

h. Meningkatkan koordinasi yang baik antara pihak kapal dengan pihak pencharter yaitu menyangkut masalah waktu. Hal ini sangat diperlukan sekali oleh pihak kapal dengan penyesuaian waktu mulai dari tempat pembongkaran ke tempat pemuatan.

\section{PENUTUP}

\section{Kesimpulan}

Berdasarkan uraian sebelumnya
dalam pembahasan mengenai
"Peningkatan keterampilan crew dalam
pelaksanaan tank cleaning guna
menunjang kelancaran bongkar muat MT.
Balongan" maka sebagai bagian akhir
dari penelitian ini penulis memberikan
beberapa kesimpulan yang diambil dari hasil penelitian dan analisa data sebagai berikut:

a. Pengetahuan dan keterampilanyang kurang oleh anak buah kapal (ABK) terhadap cara pembersihan tangki yang baik dan efisien.

b. Kurangnya waktu yang diberikan oleh pihak pen-charter terhadap pihak kapal khususnya dalam proses tank cleaning.

\section{Saran}

Mengingat begitu besar peranan proses pembersihan tangki terhadap kelancaran operasional kapal dalam menerima muatan baru, maka proses pelaksanaan pembersihan tangki di atas kapal hendaknya dilaksanakan secara benar. Untuk mendapatkan hasil yang optimal dan sesuai dengan ketentuan peraturan yang berlaku dalam kesiapan kapal dalam menerima muatan baru.

Dari beberapa kesimpulan di atas, masih ada beberapa kekurangan dalam proses pelaksanaan pembersihan tangki secara benar, maka penulis memberikan saran-saran sebagai berikut:

a. Sebelum dilaksanakan pembersihan tangki sebaiknya terlebih dahulu diadakan suatu meeting yang membahas tentang rencana kerja, pembagian kerja dan pelaksanaan kerja sesuai prosedur pembersihan tangki yang benar. Sehingga nantinya tidak terjadi kekacauan dan kerancuan dalam pelaksanaan pembersihan tangki yang bisa berakibat fatal. Peningkatan kemampuan sumber daya dan kualitas crew kapal hendaknya didukung dengan mengikuti kegiatan pelatihan keterampilan Tanker Familiarization Course (TFC) dan peningkatan ijasah pelaut yang diselenggarakan di diklat-diklat kepelautan. Disamping itu sebagai nakhoda dan perwira di atas kapal terutama Mualim I harus selalu memberikan pengawasan dan pengarahan serta turut dalam mengawasi kegiatan anak buah kapal 
(ABK) pada saat melaksanakan pekerjaannya. Tujuannya agar dapat disiplin dan mempunyai motivasi dalam setiap pekerjaannya sehingga dapat menunjang keterampilan dan pengetahuan para anak buah kapal (ABK).

b. Meningkatkan waktu yang dibutuhkan dalam proses pembersihan tangki. Hal ini dapat terealisasi dengan cara menyesuaikan rute pelayaran. Sehingga dengan bertambah jauhnya perjalanan kapal dari pelabuhan bongkar ke pelabuhan muat, maka waktu yang dibutuhkan dalam proses pembersihan tangki juga akan bertambah banyak. Disamping itu pentingnya disiplin waktu dalam pekerjaan tank cleaning di atas kapal agar waktu yang diberikan oleh pihak perusahaan dapat digunakan dengan baik.

\section{DAFTAR PUSTAKA}

Anggoro, Toha. 2011. Metode Penelitian Revisi. Jakarta: Universitas Terbuka

Marton, G.S. 2007. Tanker Operation Fifth Edition. England: Mary Land

Martopo, Arso. 2008. Penyunting ISM Code Amanded in 2002. Jakarta: Pusat Pendidikan dan Pelatihan Perhubungan Laut

Moleong, Lexy J. 2006. Metodologi Penelitian Kualitatif. Bandung: PT Remaja Rosdakarya

Undang-Undang Republik Indonesia No. 17 Tahun 2008 tentang Pelayaran

Verweys, D. R. 2007. Tank Cleaning Guide. Rotterdam 